\title{
Why Positivism is Authoritarian
}

\author{
David Dyzenhaus
}

\author{
Version Publisher's Version \\ Citation David Dyzenhaus, "Why Positivism is Authoritarian" (1992) 37 \\ (published version) American Journal of Jurisprudence 83. \\ Publisher's Statement This is a pre-copyedited, author-produced version of an article accepted \\ for publication in American Journal of Jurisprudence following peer \\ review. The version of record [David Dyzenhaus, "Why Positivism is \\ Authoritarian" (1992) 37 American Journal of Jurisprudence 83] is \\ available online at: https://doi.org/10.1093/ajj/37.1.83 .
}

How to cite TSpace items

\begin{abstract}
Always cite the published version, so the author(s) will receive recognition through services that track citation counts, e.g. Scopus. If you need to cite the page number of the author manuscript from TSpace because you cannot access the published version, then cite the TSpace version in addition to the published version using the permanent URI (handle) found on the record page.
\end{abstract}

This article was made openly accessible by $U$ of $T$ Faculty. Please tell us how this access benefits you. Your story matters. 


\section{WHY POSITIVISM IS AUTHORITARIAN}

\section{David Dyzenhaus*}

\section{INTRODUCTION}

Legal positivism is the leading doctrine about the nature of law. Its proponents insist that a realistic understanding of law must respect a distinction between law as it in fact is and law as we would like it to be. But like Dr. Jekyll and Mr. Hyde, legal positivism seems to lead two distinct lives, one virtuous and one wicked. As Jekyll, and as its proponents claim, legal positivism is a doctrine about the nature of law that, correctly understood, can only help to inculcate morally desirable attitudes towards the law in both judges and citizens.

As Hyde, and as its critics claim, positivism's slogan "Law is law" is the legal expression of the authoritarian ideology which states that judges have a moral obligation to apply, and citizens to obey, the law whatever its content. Such critics have tried to show what it is about theoretical Dr. Jekyll that might make him haunt the practice of law as Mr. Hyde. But positivism's place as the leading doctrine about the nature of law is testament to the difficulty of that task.

This century's most powerful attempt to portray positivism as Hyde is Ronald Dworkin's critique of H.L.A. Hart's positivist conception of law. But his critique might merely seem to illustrate the impossibility of dislodging positivism.

For Dworkin, the conflict between his theory of law and that put forward by legal positivism is one between rival and deeply political ideals of the rule of law. As is well known, his critique of positivism turns on claims about the judicial obligation in "hard cases"-cases on contested points of law. According to him, positivist judges will decide such cases in accordance with an impoverished ideal of the

* This essay elaborates ideas put forward in my Hard Cases in Wicked Legal Systems: South African Law in the Perspective of Legal Philosophy (1991). It arguments have been constructed at various times under the critical gaze of Ronald Dworkin, John Finnis, Jeffrey Jowell, Neil MacCormick, Cheryl Misak, Madison Powers, Joseph Raz, Athur Ripstein, Michael Taggart, Graham van der Leeuw, Ernie Weinrib and an anonymous reviewer for this Journal; I thank them all for very helpful and often highly sceptical comments. 
rule of law, one which assumes the distinction between law as it is and law as it ought to be. Such judges will thus fail to make of law the "best that it can be," an enterprise which is undertaken only when judges reject the positivist distinction and see law as a matter of moral principles already inherent in the law. ${ }^{1}$

But contemporary positivists deny that their theory of law is driven by any political ideal; it merely reflects and explains the nature of law. That theory is expressed in Joseph Raz's "Sources Thesis" which says that what law is is determined purely as a matter of social fact, that is, without resort to moral argument. ${ }^{2}$ Since hard cases are in part determined by argument about what follows from moral principles embedded in the law, it follows that the decision of hard cases is determined not by law, but by an act of discretion or judicial legislation ultimately unconstrained by law. It also follows that the correct theory about the nature of law is not committed to any account of how such cases should be decided. Thus it seems that one cannot criticize legal positivism on the basis of what judges do in hard cases. The debate between Dworkin and contemporary positivists seems at an impasse on this issue.

But positivism might seem to win the day because of a strikingly implausible claim which seems entailed by Dworkin's theory of law. The claim arises because of the existence of wicked legal systems. A wicked legal system is one which meets all the criteria we might suppose are sufficient for the existence of a legal system and whose laws have relentlessly been made the instrument of a repugnant moral ideology. Here the standard example is the South African legal system insofar as it has been made the instrument of apartheid ideology. It will seem that Dworkin must say that it is a South African judge's duty to decide hard cases on the interpretation of apartheid laws in terms of the principles which best explain and justify those laws; that is, hard cases should be resolved in the light of apartheid policy. ${ }^{3}$ Thus the existence of wicked legal systems provides a second reason why the terrain of adjudication might seem most unpromising as a basis for a Dworkinian critique of the positivist distinction between law as it is and law as it ought to be.

1. Dworkin, Law's Empire (1986).

2. Raz, The Authority of Law (1979), pp. 38-40. My arguments about positivism do not apply to the positivist theory of law put forward by Hans Kelsen. The "incorporationist" off-shoot of legal positivism, which holds to a modified version of the Sources Thesis, is discussed below.

3. Raz, "Authority, Law and Morality," 68 The Monist (1985), p. 309.
In Hard Cases in Wicked Legal Systems: South African Law in the Perspective of Legal Philosophy, ${ }^{4}$ I attempt to show not only that the terrain of adjudication supports Dworkin's thesis, but that this is best appreciated in a case study of what should be the most unpromising terrain of all: the adjudication of hard cases on the interpretation of apartheid laws.

There I describe how the great majority of South African judges adopted a positivistic distinction between law as it is and law as it ought to be, and so interpreted apartheid laws in accordance with what the judges took to be "plain facts" about legislative intentions. As a result, "plain facts" judges interpreted apartheid laws just as the government wanted them interpreted.

By contrast, judges who rejected this distinction interpreted the law as Dworkin would recommend, by seeking to make law live up to the promise of moral principles which they took to be part of their common law tradition. This "common law" approach required legislators to be explicit, should they be so minded, that their statutes not be interpreted in accordance with such principles.

Thus the plain fact approach, in allowing legislators to avoid being explicit about their intentions, also allowed the government to operate under a misleading facade of the rule of law. In other words, the plain fact approach afforded the South African government a degree of legitimacy which the common law approach withheld.

The positivist response to my claims is naturally to disown the plain fact judges. Positivists will say that when judges decide hard cases in accordance with a plain fact approach, they are merely exercising their discretion in accordance with conservative values. Moreover, positivists will maintain that had these judges been required to acknowledge that they were exercising a discretion, they would have been accountable for their decisions in a way precluded by the Dworkinian assumption that their answers were fully determined by law. That is, the positivist theory of law would not dictate an answer in such cases, but merely make it clear that judges had to exercise a discretion. As a result, judges would have had to take responsibility for their choices, instead of hiding, as Dworkin's theory might seem to encourage, behind a fiction of law-finding.

Here I will argue that plain fact judges make the only sense of positivism which it is possible for judges to make. In particular, I

4. David Dyzenhaus, Hard Cases in Wicked Legal Systems: South African Law in the Perspective of Legal Philosophy (1991).

5. See, for example, Hart, "Positivism and the Separation of Law and Morals," Essays in Jurisprudence and Philosophy (1983), pp. 67-68. 
will try to show that legal positivism contains two pragmatic tendencies, one authoritarian and one progressive, and that only the authoritarian tendency is capable of informing judicial activity.

My argument consists of two parts. First, I will sketch the positivist tradition that runs from Thomas Hobbes through Jeremy Bentham to John Austin. That sketch will show how two warring tendencies come to be implicated in the same theory of law. Secondly, I will argue that Hart and Raz do not succeed in distancing contemporary positivism from the authoritarian tendency that drives a plain fact approach.

\section{HobBesian Positivism}

By a pragmatic tendency of a theory, I mean the effects which that theory aims to have and in fact does tend to have on practice. As I have suggested, positivists do not ultimately assert that we should adopt their theory for pragmatic reasons-because it would make practice go better. Rather they advance conceptual or analytic reasons-legal positivism simply represents the truth about law: ${ }^{6}$

My argument about pragmatic tendencies in legal positivism starts with two of Lon L. Fuller's neglected insights into legal theory. Fuller suggested, first, that positivism was not always unpragmatic in the way that twentieth-century positivism is. Secondly, he suggested that Thomas Hobbes' "ethical positivism" contains the hidden pragmatic agenda of twentieth-century legal positivism.?

By contrast with Hart and Raz, Hobbes is a dyed-in-the-wool pragmatist. ${ }^{8} \mathrm{He}$ puts forward a positivist theory of law because, he thinks, such a theory will solve a social and political problem which a common law conception of law can only make worse. And in so doing, he provides a political doctrine of responsibility for judges which requires them to use a plain fact approach.

Hobbes diagnosed the cause of the social and political discord of his day as the inability of the "natural" reasons of individuals to transcend their particular desires. His "subjectivism"-his belief that there is no more to individual reason than an expression of desire-

6. For an early discussion, which seems to suppose that the issue of what law is is settled first and foremost by theoretical considerations, see Hart, The Concept of Law (1961), pp. 205-06. See also Raz, "The Problem About the Nature of Law," 21. U. of W. Ont. L.R. (1983), p. 203; and Hart, "Comm Antemporary Jurisprudence, The Influence of H.L.A. Hart (R. Gavison, ed. 1987), p. 35. 7. Fuller, The Law in Ouest of Itself (1940), pp. 19-21.

8. In what follows, I rely mainly on T. Hobbes, Leviathan (C.B. MacPherson, ed. 1985). Pagination in square brackets is that of the original text. led him to suppose that individuals in a state of nature must end up in a war of one against all because of the inevitable clash of particular, natural reasons. His solution to this problem is an omnipotent sovereign-a person whose will, expressed in his commands, is taken as an artificial standard of right reason by all individuals, thus giving them a stable foundation around which to coordinate their activity. ${ }^{9}$

Hobbes is led to a positivist conception of law because it is that conception which can do the job of coordination. ${ }^{10}$ The identity of the sovereign himself, what he intends to be taken as his will, and the content of his will, have to be uncontroversially determinable. If controversy breaks out at any of these steps then individuals are thrown back on the useless resource of their natural reasons. In order for controversy to be preempted, the sovereign, his commands, and their content must be ascertainable by purely factual and publicly accessible tests. In particular, commands must be such that subjects will know that they should do something merely because the sovereign has said so, and without having to resort to their natural reason to determine what it is

Command is when a man saith Doe this or Doe not this yet without expecting any other reason than the Will of him that sayes it. ${ }^{11}$

That is, the command must have the attribute which Hart later called "content-independence" - it must be such that its content is determinable in a purely factual manner. ${ }^{12}$

Thus Hobbes rejects a common law conception of law just because it supposes that one cannot determine what law is without resort to standards of justice and reasonableness whose determination is the special province of lawyers and judges. That conception is, in his view, a recipe for controversy and strife. And a conception of law which says that law is a system of commands which meets a Sources Thesis, one which looks only to publicly accessible facts and not to moral argument, is the means for implementing Hobbes' solution to the problem of social order..$^{13}$

Hobbes argues further that there is a prior moral obligation on all citizens of a particular commonwealth to obey the civil law contained

9. Ibid., Ch. 13

10. Ibid, Ch. 13.

11. Ibid., Ch. 25 , p. 303 [131], his emphasis.

12. Hart, Essays on Bentham (1982), pp. 254-55.

13. Leviathan, Ch. 26, pp. $319-22$ [141-44]. 
in the commands of their sovereign. He asserts that there is one standard of right reason-a standard which all individuals should rationally agree transcends the clash of individual reasons-the preference for any order over chaos. Since the commands of the sovereign are the only thing that can promote order, the commands are legitimate whatever their content. Hobbes recognizes of course that not all individuals will accept his assertion that they can rightly be taken to have consented to the system of positive law in which they happen to find themselves. And so he requires that sanctions be attached to the commands of the sovereign in order that individuals who have not grasped their obligation to obey the law will still obey on pain of punishment.

On this same authoritarian argument, judges are obliged to apply and enforce the law whatever its content. Even if a judge has assumed office because he favors the official policy of the law, he must apply the law as he finds it and not the law as he would like it to be. $\mathrm{He}$ must not let his judgment as to the correct version of the official policy influence the process of interpretation. Hobbes' argument requires officials, including judges, to adopt a conception of law as the commands of the sovereign determinable by" public and factual tests.

So Hobbes' argument makes it very clear what judicial responsibility is. Judges are morally obliged to enforce the law as it exists, which means the commands of the sovereign whose content is to be determined by purely factual and publicly accessible tests. Their primary function is executive-to execute the will of the sovereign as he intended it to be executed.

By contrast with contemporary positivists, Hobbes thinks that judges should endeavor to fulfill their executive function even, perhaps especially, when it appears unsettled what the law is on a matter. He notes that his theory of law requires a theory of interpretation or adjudication and he makes it plain that it is the political ideal fundamental to his theory of law which should inform a judge's understanding of responsibility in hard cases. Judges should seek to be true to their executive function and thus should develop and resort to interpretative tests which aim at determining what the sovereign as a matter of public fact intended. Only when such tests come up empty can such judges feel justified in resorting either to their natural reason or to the common law. This resort is, on Hobbes' approach, to be avoided as far as possible. ${ }^{14}$

14. Ibid., pp. 322-29 [142-47]; and see note 21
Indeed, the idea that judges have to exercise a discretion in such circumstances comes naturally to Hobbes. For him a genuine hard case is not one in which there is merely some controversy about what law is. It is one in which there is no discoverable fact of the matter about what the sovereign intended. Given his scepticism about the resource of individual natural reasons, judges must by definition decide such hard cases in a manner which is arbitrary or irrational since only the content of positive law is non-arbitrary or rational Such arbitrariness is remedied only insofar as the sovereign might either expressly or by silence acquiesce in the judgment.

Hobbes' positivism thus provides a theory of law which includes a political doctrine of judicial responsibility capable of driving a plain fact approach in the context of a wicked legal system. Indeed his theory of law seems designed precisely for a society in which executive officials need an argument to justify applying and enforcing laws which are regarded by a significant number of the population as oppressive. While sociologically, as it were, it will be the case that many of these officials, including judges, will regard the law as legitimate because they like its content. They need a reason to justify enforcing that law against subjects who find it oppressive. That reason is an alleged obligation to prefer any order to the chaos that results when order disintegrates.

Notice that this picture of Hobbes' political justification for a positivist theory of law which tells judges what to do in hard cases does not on the surface show any pragmatic tension. The pragmatic tendency of his legal theory seems entirely authoritarian. And I will argue below that the pragmatic tension is produced in contemporary legal positivism mainly by the way in which contemporary positivists graft some of Bentham's concerns on to a basically Hobbesian theory of law. However, it is important to see the roots of that tension in Hobbes.

\section{The Pragmatic Tension In Hobbes}

The tension is nicely illustrated by David Gauthier's recent attempt to vindicate a basically Hobbesian political justification for a positivist theory of law. Gauthier's essay has three main themes. ${ }^{15}$ First, he says that Hobbes was not a positivist because Hobbes did not argue that the obligation to obey the law came from within law. Secondly,

5. D. Gauthier, "Thomas Hobbes and the Contractarian Theory of Law," 16 Can. J. of Phil. (1990) 
he argues that Hobbes did not believe that might makes right. For Hobbes, it is not the mere fact that there is a sovereign capable of enforcing the law that makes law morally obligatory. Rather it is the fact that there is a prior moral obligation to obey such a sovereign that puts his subjects under both a moral and a legal obligation.

Thirdly, Gauthier points to some problems in the way in which Hobbes' political justification for the legitimacy of positive law and his account of the institutions of positive law mesh. These boil down to one fundamental problem. Hobbes, as we have seen, wants his political justification to rest ultimately on the hypothetical consent of individuals. Individuals will rationally consent to any order over chaos because it is in their interests to do so. But the basis of his argument for hypothetical consent is in tension with his claim that any political order is legitimate.

Hobbes bases his argument for hypothetical consent on his conception of the natural right of liberty and the laws of nature. ${ }^{16}$ The right of liberty is the right that each individual has to do anything necessary for self-preservation. Laws of nature are those laws which prohibit individuals from acts which in fact will lead to self-destruction. The first and fundamental law of nature is to seek peace and, only when peace cannot be obtained, to resort to a war of self-defense. Hobbes thus reasons that contracts which violate the laws of nature are void because individuals cannot rationally contract to do anything which is self-destructive. For example, an individual cannot be taken to have rationally consented to be injured or killed.

Three of the further laws of nature are particularly important here. The second law of nature requires of each individual that he give up so much of his own natural right as he would ask of all other individuals that they give up for the sake of his self-preservation. The third law of nature says that men should perform their covenants and that justice is the performance of covenants according to their terms. The eleventh law of nature requires that equity be respectedanyone who has the job of judging between individuals must deal with them equally. To deal with them partially is against the law of nature and likely to lead to war.

The problem for Hobbes is that he wants to say that all legal subjects have hypothetically contracted with the de facto sovereign to recognize his commands as legitimate. Disobedience to his commands; whatever their content, is unjust. But the possibility exists that the sovereign will infringe the laws of nature. Indeed, as Gauthier

16. Leviathan, Ch. 14 and 15.

\section{DAVID DYZENHAUS}

points out, the sovereign has to infringe at least the first law since it is essential to his success that he exercises his power to punish disobedient subjects. ${ }^{17}$ But such subjects are entitled by the first law of nature, the very law which generates the argument for hypothetical consent, to resist punishment because punishment is destructive of the self.

Similarly, if the sovereign enacts law which is partial as between individuals, he infringes the law of equity. Hobbes adverts to both of these problems when he says that "It is true that they that have Soveraigne power, may commit Iniquity; but not Injustice, or Injury in the proper signification.",18 Legal subjects seem then to have in certain circumstances a natural right of resistance which they are morally obliged not to exercise.

Gauthier argues that these problems indicate that a contractarian political theory which is more generous than Hobbes' about the scope of individual natural reason might play a significant role in determining the scope of authorization to the law giver. ${ }^{19}$ For example, one might build any number of standard liberal, individual rights into the picture of what individuals would rationally agree to, and then argue that the scope of the sovereign's authority to make law is limited by those rights.

But even if Gauthier can show why contemporary contractarians should adopt some package of individual rights, those to which all rational individuals would agree, we have to ask whether this would not require rejecting Hobbes' positivist account of law. For Hobbesian positivism is in pragmatic tension with what such a package tries to achieve.

What makes any brand of positivism distinctive is the positivist insistence on the distinction between law as it is and law as it ought to be. If a requirement of respect for individual rights is incorporated into one's criteria for the validity of law, then that distinction, at least from the perspective of Hobbesian positivism, breaks down. For it will be up to some body of judges to decide whether the sovereign's commands are law in accordance with the requirements of natural reason, which will invite the chaos which Hobbes' positivism is designed to preempt. The only way for judges to avoid chaos is to interpret the law in accordance with the sovereign's sense of how the rights best cohere with his commands; that is, by adopting

17. "Thomas Hobbes and the Contractarian Theory of Law," pp. 26-31. 18. Leviathan, p. 232 [90].

19. "Thomas Hobbes and the Contractarian Theory of Law," pp. 33-34. 
something like the plain fact approach required by a Hobbesian doctrine of political responsibility. But then the rights are playing no role at all in limiting the scope of valid public reason.

My suggestion is that one cannot without tension have in the same theory a role for standards of right reason as a check on legislative authority and a Hobbesian account of positive law which is meant to be the instrument of those standards. The most one can manage is something which I think Hobbes can be said to have in mind. One can recommend to the sovereign what one thinks are standards of right reason and hope that he will abide by them. ${ }^{20}$

So, by contrast with Gauthier, I want to say that Hobbes is a positivist because of the way in which his political theory meshes with his theory of law. And I want to say that for Hobbes might is right because from the standpoint of judge or legal subject there can be no standards of right reason other than what the sovereign has declared to be right. As we have seen, Hobbes is sometimes unclear about what happens when civil law contravenes his principles of natural law. However, he time and again asserts unambiguously that for judges and other officials charged with executing the sovereign's commands, not only justice but all the principles of natural law, including equity, are what the sovereign says they are. And he makes it plain that judges in their interpretation of the law must do their best to determine what the sovereign's view of equity and justice would be. Hobbes comes down at every crucial point in favor of the claim that judges and executive officials must assume that there is a moral obligation on legal subjects to obey the civil law and on judges to apply that law, whatever its content. ${ }^{21}$

20. If the sovereign himself decides to enact into the law a package of liberal rights and freedoms against which the validity of other legislation is to be tested, the problem does not go away. Fuller called this particular instance "The the ppen of the Inconsiderate Sovereign" and by this he meant that the sovereign was being inconsiderate of the political ideal which animates legal positivism; Fuller, The Law in Quest of Itself, pp. 34-41. For if law incorporates substantive moral standards in this way it can no longer perform the function it is supposed to-to act as a political "debate stopper." [See Gerald Postema, Bentham and the Common Law Tradition (1986), pp. 463-64.] One might well suppose that in the case of an inconsiderate sovereign, Hobbes must recommend that judges avoid chaos in the manner just suggested.

One might also then suppose that when the sovereign's commands flout the laws of nature, judges should interpret the commands differently than he intended in order to help law serve its social function of preserving peace. But it seems that Hobbes cannot, on pain of contradiction, make this recommendation.

21. See Leviathan, Ch. 26, pp. 314-15 [138-39], where the claim is reiterated that, from the perspective of legal subjects, the laws of nature must be taken to be
Finally, I want to repeat my argument above, that Hobbesian positivism makes best sense when judges have to enforce law which violates what a significant number of legal subjects take to be just. Contemporary positivists, however, take Jeremy Bentham as their founding figure and not Hobbes; and Bentham was genuinely antiauthoritarian. Clearly, I still have some distance to go in my argument that positivism is authoritarian.

\section{BENTHAM's ANTI-AUthoRITARIANISM}

The contemporary positivist claim to be anti-authoritarian has an uncontestable basis in Bentham's work, since his positivism is developed in the service of a far-reaching theory about the benefits of democracy. But that is just my point. While Bentham's position differs in most fundamental respects from Hobbes', they share one important feature. Bentham, no less than Hobbes, is a pragmatist; his positivism is put forward as the theory of law one should adopt in order to make practice go better.

Bentham wants law that lives up to the positivist distinction between law as it is and law as it ought to be, not for the Hobbesian reason that such law preempts the resort of individuals, including judges, to natural reason. He wants law of this kind because it facilitates the deliberation of right individual reason, which he takes to be reasoning on the basis of utility. Hobbes' scepticism or subjectivism

contained in the civil law.

In Leviathan, Hobbes also says that "It is true that they that have Sovereigne power may commit Iniquity; but not Injustice, or Injury in the proper signification"; $\mathrm{Ch}$. 18 , p. 232 [90]. And in Ch. 26, p. 326 [145], he says:

Now the Intention of the Legislator is alwayes supposed to be Equity: For it were a great contumely for a Judge to think otherwise of the Soveraigne. He ought therefore, if the Word of the Law doe not fully authorise a reasonable ought therefore, if the Word of the Law doe not fully authorise a reasonable
Sentence, to supply it with the Law of Nature; or if the case be difficult, to Sentence, to supply it with the Law of Nature; or if the case
respit Judgment till he have received a more ample authority.

This passage is, perhaps deliberately, ambiguous between, "Judges can resort to their own understanding of what the laws of nature require," and "Judges should their own understanding of what the laws of nature require," and "Judges should the will of the sovereign." However, Hobbes' suggestion that the sovereign can act inequitably but not unjustly is made from the perspective of the state of nature, from which no principles of justice can be deduced other than the principle that justice is the justice of some system of positive law, but in which there is an unenforceable duty to act equitably. Once there is a system of positive law in place, for judges and other legal subjects the content of equity, like the content of justice, is to be found in that law. [Compare Hobbes, A Dialogue Between a Philosopher and a Student of the Common Laws of England (J. Cropsey, ed. 1971), p. 101.] 
about reason is matched by Bentham's generally optimistic confidence in the rational ability of individual reasoners. ${ }^{22}$

Bentham thought that the law enacted by the legislators should be certain in the sense of being factually determinable by publicly accessible tests. However, his emphasis on positive law is not one designed to preempt individual reason but to facilitate it. Because positive law is certain and predictable it provides the secure basis on which an individual can calculate the utility of doing this rather than that. Further, positive law provides the basis onto which general expectations can fasten. Citizens will have to take into account in their calculation both the pain of suffering a sanction in the event of deciding to disobey the law and the reasons for following the law, which will include its utility and the weight appropriately accorded to the fact that others will expect compliance. But they are not under any moral obligation to obey the law merely because it is a law. The only moral obligation for an individual is to act in accordance with utility.

Similarly, even when the law is clear, judges have to calculate whether utility requires that they apply it. This apparent license to judges is not a problem for Bentham's mature virew, since he argued ultimately that judicial decisions should not have legal force beyond the decision between the parties. In other words, he advocated getting rid of "judge-made" law or precedent altogether.

In Bentham's ideal society, judges would adjudicate in the shadow of a code, enacted by enlightened legislators. Legislative enlightenment would be ensured by a system of comprehensive democratic controlsa free press, frequent elections, and a right of recall over incompetent legislators. In cases of indeterminacy of law, or when judges found that the law caused injustice in a particular case, judges should, he thought, decide the matter in accordance with utility. But their decision would have no legal effect except as between the parties and the matter would then be referred to the legislature for proper decision. ${ }^{23}$

Bentham's conception of the role of law does not, I suggest, give rise to the plain fact approach. For Bentham, legitimate law is the command of a legally unlimited legislature, but not for the (Austinian) reason that the sovereignty of the legislature cannot by definition be

22. I rely here on Bentham, $A$ Comment on The Commentaries and $A$ Fragment on Government (J.H. Burns and H.L.A. Hart, eds. 1977); Bentham, Constitutional Code (F. Rosen and J.H. Burns, eds. 1983); and on Postema, Bentham and the Common Law Tradition.

23. See Bentham, Constitutional Code. legally limited. Bentham is opposed to the division of legal sovereignty because for him judge-made law is illegitimate. Law is legitimate when and only when it is the expression of a democratically elected and controlled legislature. Further, the sting is to a large extent taken out of the command because it is not supposed to preempt either evaluation of the content of the command or action on the basis of a negative evaluation. Bentham's conception of the role of law is therefore appropriate only in the kind of political structure which demands of judges that they decide all cases by reference to utilitarian principles of substantive justice. Something like the plain fact approach might be appropriate for determining legislative intent, but the intent determined is never privileged in the way Hobbes requires.

In sum, Bentham's positivism avoids Hobbesian authoritarianism because he tells both legal subjects and judges that utility and not the law is the arbiter of what should be done. Indeed, he does not propose anything like a doctrine of political responsibility to law that judges should adopt. In the context of his general model of political society and legal order, it makes sense for him to propose that the only political responsibility judges have is to utility.

Nevertheless, Bentham does not altogether avoid the pragmatic tension I showed to be embedded in Hobbes' political theory. His motto "to obey punctually, to censure freely," which Hart takes as definitive of the anti-authoritarianism which legal positivism promotes, ${ }^{24}$ is not in any simple way anti-authoritarian. The motto does not say that subjects should refuse to obey the law merely because the law violates utility. Instead it says that if the law is immoral, it should be obeyed and then criticized vigorously in the cause of legislative reform. So Bentham thought that in the case of laws perceived to be immoral, utility dictated that the question as to what should be done about the laws should be referred to the legislature. His model legal system locates all significant checks on legislation in a culture of legislative responsiveness to the public.

His model legal system thus allows no room for the argument of contractarian and other philosophers who think that there are substantive moral standards which should inform the legal constitution of political society. This thought is anathema to Bentham, whether the standards are said to be implicit in the law or, even worse, are made explicit in an enforceable charter of rights. For then one must resort to judicial determinations of legal validity in terms of subjective perceptions of right and wrong. But if one supposes that the historical

24. A Fragment on Government, p. 399 (emphasis omitted); "Positivism and The Separation of Law and Morals," p. 53. 
record shows the need for such charters in order to curb the authoritarian excess of which representative government is capable, John Stuart Mill's "tyranny of the majority," Bentham's model of law will not appear to escape being authoritarian. Nevertheless, Bentham's strategy is clearly to develop a positivist model of law which will serve an anti = authoritarian, democratic political morality.

\section{Austin's Authoritarian PositivisM}

Austin is most remembered for this sentence in his Lectures on Jurisprudence: "The existence of law is one thing; its merit or demerit is another." 25 Indeed, it may fairly be said that it is on this sentence that Hart's and Raz's positivism rests. For while Hart constructed his own concept of law by a strategy of progressive demolition of the elements of Austin's concept, ${ }^{26}$ he always remained committed to the positivist distinction between law and morality.

It might seem then that Austin should be claimed as the founder of Analytical Positivism, the contemporary version of positivism which seeks to analyze the concept of law as it actually exists in legal practice rather than constructing a conception of law in the service of some normative, political ideal. This analytic project is thought to have been begun by Bentham, though Hart and other contemporary positivists sometimes express their concern about what they regard as Bentham's capricious tendency to confuse normative and legal inquiry. ${ }^{27}$

However, if the snapshot of Bentham's project just outlined is accurate, the distortion goes the other way. Contemporary positivists, because they insist that inquiry into the nature of law must respect an analytic distinction between law as it is and law as we would like it to be, force Bentham's work into a Procrustean bed which severs its most important limb. They reduce the normative basis of Bentham's work to the status of some discrete anomalies, which can be cursorily dismissed.

I want to suggest that even Austin does not quite fit the role of founder of the contemporary positivism which makes a hard and fast analytical distinction between enquiry into law and enquiry into morality. To read Austin as the first purely analytic positivist is to ignore entirely Austin's treatment of authority in the third of his Lectures on Jurisprudence. ${ }^{28}$ In this lecture, Austin outlines a theory of authority which leads to a picture of a political society based on utilitarian principles very different than Bentham's.

25. Austin, Lectures on Jurisprudence (R. Campbell, ed. 1885), vol. 1, p. 214. 26. The Concept of Law.

27. See, for example, The Authority of Law, pp. 166-67.

28. I am greatly indebted for this insight to R.B. Friedman, "An Introduction
Austin does not argue for Bentham's radical democracy in which each individual is the ultimate arbiter of what should be done. His political and legal theory is much more akin to those rule-utilitarian philosophies which suppose that consequentialist justifications for moral truths might have to be kept concealed from the public. Austin puts forward a version of what Bernard Williams and Amartya Sen aptly describe as "Government House Utilitarianism": "An outlook favoring social arrangements under which a utilitarian elite controls a society in which the majority may not itself share [the beliefs of the elite]."29

Austin, like Bentham, is not a Hobbesian subjectivist. With Bentham he holds that correct answers to even the deepest questions about morality are given by an appropriate utilitarian calculation. Where he differs from Bentham is his lack of confidence in the "multitude" of his society to be trusted with the business of making. such calculations. He describes them as given to "coarse and sordid pleasures," people with a "stupid indifference about knowledge." 30

To the extent that the multitude of his day is unenlightened, and to the extent that they are doomed to at least some measure of general ignorance, they can legitimately, Austin thinks, be subjected to the dominion of authority. By .authority he means exactly what Hobbes meant-a system of commands which subjects must take as conclusive as to what to do on pain of suffering a sanction if they do not follow the command. ${ }^{31}$

Austin's account of authority faces two problems. First, he makes no claim that an elite of experts actually exists who have developed the science of utility to the point where they are entitled to exercise the dominion of authority. Thus the status of his theory as a working model for the society of his day is unclear. Secondly, given that the multitude is justifiably subjected to the rule of such an elite because of their inability to make the right decisions, it is mysterious how the multitude can be expected to recognize the elite as their legitimate master.

The first problem might seem to save Austin from the charge of authoritarianism since he does not suppose that an elite is entitled

to Mill's Theory of Authority," Mill: A Collection of Critical Essays (J.B. Schneewind, ed. 1968), p. 379. Hart, in his introduction to a collection of Austin's work, shows that in regard to Austin as well as Bentham, positivists are troubled by a tendency to confuse the normative and the legal; The Province of Jurisprudence Determined (1965), p. xv.

29. "Utilitarianism and Beyond," Utilitarianism and Beyond (A. Sen and B. Williams, ed. 1982), p. 16.

30. Lectures on Jurisprudence, vol. 1, p. 134

31. Ibid., pp. 88-91. 
to rule just because it holds power. An elite, on his view, rules legitimately only when it is composed of experts in the science of utility. Many will find this elitist doctrine in itself authoritarian since it removes from the multitude the power to determine whether or not the law as it is deserves their allegiance. But, more importantly, there are several considerations which suggest that Austin's approach tends towards an even more thoroughgoing authoritarianism.

Austin's emphasis on coercion as part of the very definition of command indicates that he sèes the need for a non-rational mark of authority-one that compels the obedience of the multitude whatever their views on the merits of the content of the command. Austin also recognizes explicitly that the obedience of the multitude will be extracted not by their conviction about the merits of obeying this or that command or system of commands, but by the fact that there will be a system of positive laws which they know they must obey on pain of coercion. ${ }^{32}$

Most important of all is Austin's debt to Hobbes. Throughout his lecture, he emphasizes his respect for Hobbes. He said that he knew:

of no other writer (excepting our great contemporary Jeremy Bentham) who has uttered so many truths, at once new and important, concerning the necessary structure of supreme political government, and the larger of the necessary distinctions implied by positive law. ${ }^{33}$

Austin opens his lectures by adopting Hobbes' definition of law. ${ }^{34}$ And he adopts Hobbes' conception of sovereignty over Bentham's because Bentham, Austin claims, forgot to notice that the supreme commander must himself be completely uncommanded. ${ }^{35}$ Like Hobbes, Austin argues that there can be no legal limitation on sovereignty, whereas Bentham thought such a limitation undesirable but not conceptually impossible.

Austin's only objections to Hobbes are, first, that he supposes that there is no absolute duty to obey the commands of the sovereign. Secondly, he rejects Hobbes' reliance on a fiction of an original contract whereby individuals can be taken to have consented to the status quo because of a supposed preference for any order over chaos.

But Austin too seems to argue for a doctrine of consent on the basis of a preference for order over chaos. The difference between

32. See, for example, ibid., p. 299.

33. Ibid., p. 281. In fact Bentham gets only four more references in the index to The Lectures on Jurisprudence than does Hobbes, and several of the former are critical while Austin generally praises Hobbes.

34. Ibid., p. 3.

35. Ibid., pp. 234-35. him and Hobbes seems just that, as Austin puts it, the doctrine is "bottomed" directly on the "principle of utility." The most important factor in his utilitarian calculation here seems to be the "uncertainty, scantiness, and imperfection of positive moral rules." For Austin, the habit of obedience of the multitude comes about either through recognition of the "utility of political government, or a preference by the bulk of the community, of any government to anarchy.",36

In addition, while Austin, like John Locke, does allow for the possibility of a general right of disobedience when this is what utility requires, as well as a right of disobedience to particular laws, again with Locke he emphasizes the dangers involved in such a calculation to the extent that it seems hardly ever appropriate. ${ }^{37}$ His first objection to Hobbes is thus of little force. Indeed, the considerations Hobbes raises against a right of resistance are almost identical. ${ }^{38}$

Significant also is Austin's emphasis with Hobbes on continuity, on looking to the body or person who successfully exacts obedience rather than to criteria of actual legitimacy. He borrows from Hobbes this definition of the sovereign:

The legislator is he, not by whose authority the law was first made, but by whose authority it continues to be a law. ${ }^{39}$

This emphasis supports the inference suggested above that, as far as the multitude is concerned, their obedience is legitimately exacted by the non-rational marks of authority-the preemption of reason and the pain of coercion.

In this regard, Austin tries to save Hobbes from the charge of being an "apologist for tyranny" by pointing out that unless one makes the mistake of confusing tyranny with monarchy, the charge is of supporting bad rule. Austin says that Hobbes and he agree about the principal cause of tyranny, which is the ignorance of the multitude of "sound political science."40 And, when it comes to telling us what is sound, Austin says that when the multitude is in a state of instruction, the form of government is a matter of indifference. But when the multitude

is in a state of ignorance the form of government "is of the highest importance." Austin clearly means that an absolute monarchy is to

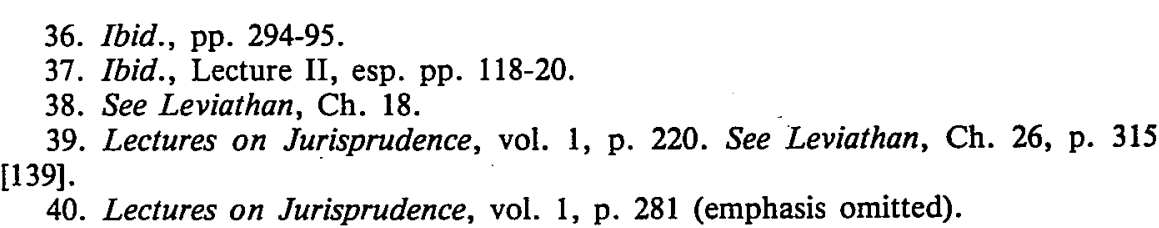


be preferred to ignorant representative government. ${ }^{41}$ But as there is a system of representative government in existence in Austin's day, his solution is the next best thing. It is government by an elite over a partly enfranchised electorate with limited control over government. ${ }^{42}$

My point here is simply that Austin's conception of law as the commands of an uncommanded commander or omnipotent sovereign lends itself to the legitimation of the law of an oppressive regime. The officials of such a regime must have a reason to regard the official policy as legitimately imposed on the ignorant multitude and Hobbes supplies the only plausible reason. It is true that Austin does not argue in so many words for a Hobbesian prior obligation to obey the law. But he claims that law, on a positivistic conception of law, gives rise to an obligation to obey the law, although he does not tell us what it is about law on this conception that is obligationcreating.

That obligation has to come from outside law. It cannot come from inside law since law is assumed to be positive law-law whose content is determinable by purely factual tests. ${ }^{43}$

We need then merely note that Hobbes' authoritarian argument supplies the answer as to why such law might be thought legitimate and that there are significant Hobbesian elements in Austin's work which distinguish him from Bentham. Austin with Hobbes puts forward a doctrine of political responsibility to law which Fuller described as a "one-way projection of authority"-a doctrine which regards legal subjects as appropriately obedient to the direction and manipulation of rulers. ${ }^{44}$

My claim that Austin establishes an authoritarian conception of law will seem at odds with his account of the judicial role. Like Hobbes, Austin argues that interpretation properly so called is interpretation which seeks out a fact of the matter about legislative intention, and that this fact is constructed in an interpretative context dominated by statutory considerations..$^{45}$ But he indicates that judges should not be limited to interpretation properly so called. He argues against Bentham that it is appropriate for judges to act as legislators. In fact, he says, the problem is not that judges have the power to

41. Ibid., pp. 282-83.

42. For Austin's hostility to anything more democratic, see his $A$ Plea for the Constitution (1959)

43. See A. Watson, Failures of the Legal Imagination (1988), pp. 125-26.

44. The Morality of Law (1969), p. 204.

45. Lectures on Jurisprudence, vol. 2, Lecture XXIX. legislate but that they have not exercised it radically enough to correct unclear or even clear but improper statutes. ${ }^{46}$

This claim goes, of course, totally against the grain of Bentham's work. It gives to judges a power which Bentham at one time was determined to limit and which later he decided had to be eradicated altogether. One can, I think, only explain Austin's claim as ad hoc, as an expression of his fear that legislators in thrall to an ignorant multitude will get things wrong. And so he gives to judges the power of enlightened correction of legislation. But that gift is in deep tension with his command theory of law and his authoritarian account of obligation under law.

\section{Contemporary Legal Positivism}

Does the same kind of tension manifest itself in the work of the contemporary positivists? This may seem unlikely when we note that Hart and Raz are more than avowedly anti-authoritarian; they also reject Austin's command theory of law. In place of the image of the sovereign as uncommanded commander, they propose as the basis of a legal system the "rule of recognition.",47

When Hart first introduced the idea of the rule of recognition into positivist legal theory, he suggested that it would cure at least two defects of the command theory of law. First, Hart said that there is more to legal order than the compulsion of a command backed by a threatened sanction. Law, he said, is surely not a "gunman situation writ large." 48 Secondly, he pointed out that the command theory of law, in putting the sovereign outside the law, does not account for the fact that "nothing which legislators do makes law unless they comply with fundamentally accepted rules specifying the essential law-making procedures." 49

On Hart's account, the rule of recognition is the most fundamental constitutional rule of a legal system, accepted by at least the officials of the legal system as specifying the criteria of validity which certify whether or not a suggested rule is a rule of the legal system. In terms of this account, legislatures are not legally unlimited even in jurisdictions where there is a strict doctrine of legislative supremacy. There the courts will recognize as valid only those legislative acts which conform to the criteria of validity in fact embedded in judicial

46. Ibid., vol. 1, p. 218 ; vol. 2 , pp. 532-33 and pp. 641-47

47. The Concept of Law, ch. 6.

48. "Positivism and the Separation of Law and Morals," p. 59.

49. Ibid. 
practice. Similarly, there will be common law or not depending on whether in fact judges have made a practice of recognizing the legal force of past judicial decisions.

So on the rule of recognition account of law, in a particular legal system we determine both what the sources of law are and what the law is by looking first to the criteria of legality in fact embedded in legal practice. The Sources Thesis is thus true because it reflects the working of the rule of recognition.

In one sense, what Hart and Raz are doing is detaching their analysis of the concept of law from any normative basis. They are denying that legal positivism amounts in any way to what Fuller called ethical positivism-versions of positivism which argue for positivism because a positivist conception of law serves some prior account of the way that political society should be ordered. But Hart and Raz are far from supposing that law lacks normativity. Law, on their conception of law, is normative in that it creates obligations for judges and subjects. Their conception is also normative in that, as they claim, it makes sense of the actual practice of law, including the normative attitudes which participants in legal practice in fact hold about law.

The sense in which Hart and Raz detach law from a normative basis is that they hold that the obligations law creates are merely legal and not moral. Law in and of itself does not live up to any political ideal capable, say, of creating a political doctrine of judicial responsibility for hard cases. They hope that the move to an account of law based on a rule of recognition together with a continued emphasis on their anti-authoritarian stance removes the sting in the command theory-the "gunman situation writ large."

Moreover, my argument about an authoritarian tendency in positivism has been one largely about a positivist ideal of judicial responsibility for hard cases. If, as Hart and Raz claim, there is no law which a judge is obliged to apply in a hard case, it follows that their conception of law does not have authoritarian implications for judges. However, there is more than sufficient reason to reject the positivist claim about discretion.

As I have suggested, the very notion of discretion is naturally supported by a sceptical attitude towards moral judgments. My claim is not that Hart and Raz share Hobbes' scepticism but that, whatever they say about this issue, it is significant that they should have adopted as a device a notion most obviously supported by a Hobbesian scepticism about reason.

Interesting here is that the "incorporationist" off-shoot of contemporary positivism seems largely fuelled by a rejection of such sceptical attitudes. Incorporationists adopt a modified Sources Thesis, in terms of which moral considerations do determine hard cases under certain conditions. ${ }^{50}$

Suppose, for example, that the rule of recognition requires deference to parliamentary legislation, and the Legislature enacts a charter of liberal rights and freedoms against which the validity of all other legislation is to be tested. Are those rights and freedoms now legal considerations? Positivists and incorporationists agree that the considerations are legal, but they disagree about whether the considerations determine the outcomes of hard cases. For incorporationists, if there is a correct moral argument based on these considerations and other relevant legal data, then there is a correct, fully legal answer to any hard case which hinges on the correct interpretation of the charter. But for Raz, that the answer is the result of moral reasoning entails that there is no legal answer, even if the reasoning is fairly easy. For him there is a fully legal answer in such circumstances when and only when the data a judge relies on are purely factual. For example, he says:

A law has a source if its contents and existence can be determined without using moral arguments (but allowing for arguments about people's moral views and intentions, which are necessary for interpretation, for example.) $)^{51}$

That is, if one can determine as a matter of fact what the Legislature intended by, say, enacting a right to equality into a charter, then that fact might determine a legal answer when the question is the application of the equality provision. But if the judge has to herself decide what the value of equality requires, then there is by definition no legal answer.

Here we can see a tension emerging which will amount to the pragmatic tension within contemporary positivism. As the moral claims positivists make on behalf of their theory of law tell us, positivists are not sceptics or non-cognitivists about morality. Why should they then insist on a theory of law and a distinction between law and morality which might seem to presuppose non-cognitivism?

In a way, this question has already been asked of Hobbes. As we saw, while Hobbes' fears are driven by his scepticism about morality,

50. See, for example, P. Soper, "Legal Theory and the Obligation of a Judge: The Hart/Dworkin Dispute," 75/1 Mich. L.R. (1977); D. Lyons, "Principles, Positivism and Legal Theory," 87 Yale L.J. (1977); W.J. Waluchow, "Herculean Positivism," 5 Ox. J. of Leg. Stud. (1985).

51. The Authority of Law, pp. 48-49. 
his hopes rest on at least one cognitivist claim-that any order is to be rationally preferred to chaos. Indeed, I tried to show that there is a basis in Hobbes' discussion of natural law for a generous cognitivist account of standards of right reason. But the difficulty, as $I$ argued, is in the combination of any more or less generous account of such standards with a positivist account of law. Such an account says both that what law is has to be determined as a matter of fact and that law of this kind creates obligations. But the only way to make sense of both of these claims is to suppose with Hobbes that the obligations are moral ones, because there is a prior moral obligation to apply and to obey the law, whatever its content.

That is, the path from the observation that a judge, to make a decision has to exercise moral judgment of "arbitrium" to the conclusion that, therefore, the decision is arbitrary in the sense of uncontrolled is a puzzling one, except on Hobbes' kind of scepticism. Contemporary positivists will say that the decision is arbitrary only from the standpoint of legal science-from the perspective of Raz's "legal man" who thinks that the requirements of law are co-extensive with the requirements of morality. ${ }^{52}$ For cognitivists the decision should not be morally arbitrary if it is subject to the scrutiny of correct morality, for example, utility. For Hobbes, the decision has to be morally arbitrary because as far as legal officials and legal subjects are concerned, there is no more to morality than the content of the sovereign's commands. But why take the perspective of the legal man as the perspective from which to understand law, unless one is committed with Hobbes to supposing that the requirements of law, on a positivistic understanding of what law is, are co-extensive with the requirements of morality?

It might seem then that a move to incorporationism defuses this point against positivists. But it does not, I think, matter whether judges adopt a modified or unmodified Sources Thesis. Plain fact judges can adopt the view that moral considerations are relevant to the decision of hard cases insofar as facts about the law make such considerations relevant. But the fact of the matter, as they understand it, is that such considerations are excluded when plain facts either expressly or by implication seem to require such exclusion.

The assumption that there will in fact be law, determined first and foremost by plain facts of the matter, provides the clue as to the rest of the story. If it makes no difference whether plain fact judges

52. See Raz, "The Purity of the Pure Theory," 138 Revue Internationale de Philosophie (1981), pp. 451-53. adopt an unmodified or modified Sources Thesis, then we can see the crucial questions that both positivists and incorporationists have to answer. Why suppose that one can ground normativity in positivistic facts about legal practices? More particularly, why should judges accept such facts as determinative of obligation of any kind? For if it is right that as far as judges are concerned only Hobbesian authoritarianism makes sense of grounding normativity in particular kinds of social facts, then we have the strongest reason to reject a positivist thesis about discretion. It is that the space of discretion of which enlightened judges are supposed to take advantage is squeezed out by the very conception of law which positivists encourage them to adopt.

In fact, when contemporary positivists do deal with the issue of judicial obligation, Hobbes haunts their work. For example, in recent work, Hart notes that Bentham rejected the Hobbesian idea that there is a prior obligation to obey the law, and of course he wants to follow suit. But he still thinks that Hobbes captured the idea of a command better then Bentham and that Hobbes' idea is illuminating for an understanding of the modern legal system. Thus he expressly adopts Hobbes' definition of a command which is meant to preempt an individual from acting for any other reason than this is what the command required. And, as Hart notes, this idea requires that the command be determinable in a content-independent way. ${ }^{53}$

Similarly, in his recent work on the authority of law, Raz has focused attention on what it takes to be one of the essential elements of authority, which he calls the "preemption thesis." Again, the thrust of such a thesis is that legal authority exists when the content of a law is such that a subject can act on it without making any substantive evaluative judgment. ${ }^{54}$ In short, both Hart and Raz argue that the authority of law cannot be understood without the Hobbesian insistence on the preemptive quality of law.

These arguments about the nature of authority tend to be quite technical. But it is revealing to see how Hart and Raz attempt to explain why judges might think themselves obliged to apply the law ascertained through a positivist process of interpretation. Raz has suggested in this regard that judges must suppose more than that they are under a legal duty to apply the law. They also have to

53. Essays on Bentham, ch. X, esp. pp. 253-55; and for Hobbes' definition of command, see text to note 11, supra.

command, see text to note 11, supra. (1985), and Authority, Law and Morality. 
suppose, or at least give the appearance of supposing, that the subjects to whom they apply the law are under a duty to obey it. Thus when judges state the law, Raz says, they make "fully committed normative statements." Raz means that judges must suppose both that they are under a moral obligation to apply the law and that citizens or subjects are under a moral obligation to obey the law. But Raz adds the qualification that judges, in asserting the binding force of the law, do not necessarily assert its moral force. ${ }^{55}$

Despite this qualification, Hart is troubled by Raz's suggestion. $\mathrm{He}$ admits that judges and other officials will often in fact believe in the moral legitimacy of their Legislature. But he sees lurking within Raz's suggestion a "formidable case" for a connection between law and morality, one which claims that a belief in the moral legitimacy of "legislative authority" must be shared by at least the officials and judges of a legal system. ${ }^{56}$

The danger Hart sees is the following. If one asserts that judges are committed to thinking that they are obliged to apply the law, one seems to have asserted something like Hobbes' prior moral obligation to apply and obey the law. Hart wants none of this, but he recognizes that Raz is trying to cope with a crucial problem. A command cannot "stand alone" as a reason for action. There must be some "ulterior reason." Hart says that all that is required is that judges "should have some comprehensible motives for behaving as they do in this respect" and this "can be easily satisfied by motives which have nothing to do with the belief in the moral legitimacy of the authority whose enactments they identify and apply as law." 57

While Hart is careful to distance himself from Raz on this point, he himself seemed severely tempted by something like the same option in earlier work. Hart had argued that a notion of official acceptance, one involving an "internal point of view," is crucial to an understanding of the operation of the rule of recognition. However, in trying to explain the notion of official acceptance, Hart equivocated between implying that acceptance involves belief in moral legitimacy and that acceptance amounts. to no more than a recognition of established official practice. ${ }^{58}$

At times, Hart suggested that in a wicked legal system one might find that only officials would accept the law as authoritative and

55. The Authority of Law, p. 155.

56. Essays on Bentham, pp. 264-65.

57. Ibid., p. 265.

58. The Concept of Law, pp. 114 and 197. that most subjects would obey only on pain of coercion. At other times, he suggested the very point he makes against Raz. He says that because the law is determined by a process of factual inquiry, established by the settled facts of judicial practice, one can decide what law is by reference to those facts alone without going into the various reasons why one might have chosen to be a judge with the legal duty to apply the law..$^{59}$ And that, he now thinks, is as far as one should go in accounting for the judicial obligation to apply settled law. ${ }^{60}$

In other words, there will be some reason upon which a judge decides to adopt the rule of recognition as the source of obligation. What matters, Hart thinks, is that the rule can function as an obligation-creating source whatever the reasons that made one decide to adopt it. It has to be significant that Hart sees the need for some additional motivating reason to adopt as authoritative a rule of this kind and that Raz's attempt to supply such a reason comes close to adopting a logic that presupposes Hobbesian authoritarianism. The natural inference is that the gap left by the absence of such a motivating reason is appropriately filled only by a Hobbesian ideal of responsibility to law. However much plain fact judges might differ about other issues, they must suppose that subjects are under a duty to obey the law whatever its moral content, and it is that thought that leads them to adopt a positivist conception of law.

My claim that Hobbes' notion of obligation is the only appropriate candidate is supported both by the failure of contemporary positivists to articulate another and by other Hobbesian traces in their account of the normativity of law. For example, the normative attitudes which Raz claims the positivist conception of law serves to systematize are without exception attitudes that express a Hobbesian view of legal process as the execution of the command of a supreme sovereign. For instance, Raz claims that when discussing appointments to the Bench, we distinguish between a judge's legal skills and his moral acumen. ${ }^{61}$ There is every reason to suppose that such attitudes exist even in benign legal systems, but why does Raz focus exclusively on normative attitudes most commonly associated with the role of executive officials as the normative elements for his conception of law?

59. Ibid., p. 165.

60. Essays on Bentham, pp. 264-65, and see his argument against Raz on the same point, ibid., pp. 157-61.

61. The Authority of Law, pp. $48-50$ 
In addition, there are significant elements in Hart and Raz's work which suggest, despite their intentions, that judges should be adopting something like a plain fact approach. As we have already seen, positivists are committed to arguing that all law is content-independent law-law whose content can be determined by purely factual tests. While they emphasize that the model of the command theory is too simple, they nevertheless suppose that on their more complex rule of recognition model, law is still in principle composed of contentindependent reasons. Indeed, for them the rule of recognition is a complex practice of such reasons since its content is stipulated to be determinable as a matter of purely factual inquiry. For example, on the positivist model, both the doctrine of precedent established by the rule of recognition and the particular rules for which precedent decisions stand have to be conceived as content-independent reasons. Legal interpretation properly so called is interpretation which meets an (unmodified) Sources Thesis. ${ }^{2}$

I find it significant here that Hart in his debate with Raz about judicial obligation slips immediately into talking about the Legislature as if the legitimacy of its law is the sole matter of concern. ${ }^{63}$ And, while Hart and Raz have dropped the notion that the law that exists is contained in the commands of an uncommanded commander, they still ask judges to regard law as the actual communications across time of legal authorities. ${ }^{64}$ And as we have already seen, Raz holds that facts about peoples' actual views and intentions on moral matters can qualify as legal facts while the conclusions of correct exercises of moral judgment cannot. Law is for positivists a one-way projection of authority.

We should also note that Raz holds that it is of the essence of law, its "specific virtue" as he puts it, ${ }^{65}$ that it provides a framework of rules whose content is ascertainable as a matter of fact. He thinks that such law provides a certain and stable basis on which people can organize their lives. $\mathrm{He}$ also points out that the content of such rules might be morally repugnant. The virtue is such only in the sense that the virtue of knives is sharpness. That is, the virtue is purely instrumental. In addition, Raz has emphasized that this virtue is a corollary of the correct view of the nature of law. Law has this virtue because of what law happens to be.

62. See Raz, "Law and Value in Adjudication," The Authority of Law.

63. Essays on Bentham, p. 265.

64. Raz explains even customary law in this way; "Authority, Law and Moral-
ity," p. 306. , 65 . 306.

65. The Authority of Law, pp. 225-26.

\section{DAVID DYZENHAUS}

109

In making this argument, Raz is trying to show how Fuller-like claims about an "inner morality" of law are in fact about a morality of instrumentality, realized when law is made as certain or factual as possible. ${ }^{66}$ But I think that Raz, in trans-mogrifying Fuller in this way, asks judges to adopt something like the plain fact approach. Especially significant here is Raz's claim about the virtue of judicial independence. In line with his claim that we distinguish between judges' legal skills and moral acumen, he says that the value of the principle of judicial independence is that it helps to ensure that judges will apply the law as it in fact exists. ${ }^{67}$ This claim is at odds with Raz's view that in common law jurisdictions judges have a discretion to overrule settled rules of common law. It also stipulatively excludes a principle of judicial independence which speaks to the importance of having judges who are free to adjudicate in accordance with the correct, morally-charged, conception of law. Such a principle, of course, does not make the sharp distinction between technical skill and moral acumen which we have seen Raz suggests we accept.

Suppose, that is, that judges think both that law is the factual communications of legal authorities and that, as such, law has the virtue which Raz asserts. We may then ask what the difference is between such judges and plain fact judges. For plain fact judges adopt Raz's conception of law as a working assumption and serve the virtue which he describes by deciding hard cases by looking to publicly ascertainable facts. They try to maximize the public ascertainability of law in what they regard as the only politically responsible manner. These judges would require some persuading as to why they should not resort to the facts about legislators' intentions when these facts are either to be found, or are directly relevant to, the statutes the judges are required to interpret.

All the positivists offer as a means of persuasion is the idea that judges have a law-making, discretionary power. And, it has to be noted, they do not claim that there are distinct borders between settled and unsettled law. Discretion, Raz emphasizes, has to be assumed; one cannot show where it starts. ${ }^{68}$ Moreover Raz has recently taken to emphasizing that discretion starts way back in

66. See Fuller, "Positivism and Fidelity to Law-A Reply to Professor Hart," 71 Harv. L.Rev. (1958) and The Morality of Law.

67. The Authority of Law,

68. Ibid., pp. 93-94; see also Raz, "Dworkin: A New Link in the Chain," 74 Cal. L.Rev. (1986), p. 1117. 
adjudication. It seems that for him both statute law and the common law are generally indeterminate. ${ }^{69}$

But to tell plain fact judges that they should merely. assume that they have discretion is politically unfeasible. If no plain facts about legislators' intentions count, then why should judges take as legally compelling even the plain fact of intention that their interpretation of the statute should be reasonably consistent with the text of the statute? Any judge would regard this sort of situation as an ad hoc Austinian invitation to engage in a wholesale and illegitimate arrogation of law-making power.

Further, when the assertion about discretion is made by positivists to plain fact judges, there is more than political unfeasibility, there is also an internal tension. Plain fact judges do not think that they have a choice between particular legal solutions. The significant choice facing them is one between what we can call "complete theories of law." Such a theory puts forward a view of what law is, a doctrine of judicial responsibility underpinning that view, and a way of resolving hard cases in accordance with that doctrine of judicial responsibility. Complete theories take up all the space available to an interpretative approach, for each is a theory about legal order and the role of judges in that order which leads to judges giving particular decisions. And the plain fact view of legal order makes sense of the positivist claim that what law is a matter of fact. It both puts that claim to work in solving legal questions and it supplies a justification in political morality for the solutions. It would certainly be strange to tell plain fact judges that they had such a discretion and to advocate at the same time a conception of law which squeezes out any space of discretion.

In other words, plain fact judges hold a doctrine of judicial responsibility which points them to what they take to be the law on the matter. To be convinced otherwise, they would have to be convinced that the law itself offers them a reason to exclude the plain facts and/or that their doctrine of judicial responsibility is misconceived. If the positivists aim to persuade judges who adopt a distinction between law as it is and law as it ought to be not to focus on the "legal" facts on which a plain fact approach fastens, they owe such judges a doctrine of judicial responsibility which will show that other considerations are legally compelling.

69. See "Dworkin: A New Link in the Chain," p. 1107, on the very limited role he now gives the rule of recognition.
I suggest, therefore, that contemporary positivists have not distanced themselves far enough from the command theory to escape the charge that their view of law encourages the plain fact approach. And they compound this by failing to offer a doctrine of judicial responsibility which could give judges an acceptable legal reason to exclude the kinds of plain facts which in a wicked legal system make the system into the worst system it could be. If a legal system like the South African one is in any way a testing ground for theories of law, the reasons for adopting the positivist theory of law cannot be moral or practical ones.

We can now see that the anti-authoritarian stance contemporary legal positivism adopts stands in a pragmatic tension with the positivist conception of law. For judges, that conception can make sense only on Hobbesian authoritarian assumptions. And while contemporary positivists want judges and citizens not to be authoritarian, they offer a conception of law which as a matter of practice will be implemented by the judges of a wicked legal system in an authoritarian way. This occurs because the political ideal which makes a conception of law as fact a sensible one within an account of judicial obligation gives rise to the plain fact approach.

Looking back, it is clear how this curious position comes about. With Austin, contemporary positivists reject Bentham's suggestion that judge-made law should not be part of a properly functioning legal system. They fail to notice that Bentham made that-suggestion because of the particular democratic political program which his positivist model of law was meant to implement. And they fail to notice that Austin reinstated judge-made law because he was no democrat.

But Austin's model of a legal system is to all intents and purposes Hobbes'. Such a model asks judges to adjudicate hard cases in accordance with an authoritarian ideal of responsibility to law and this ideal makes sense for adjudication of a view of law as fact. Contemporary positivists are anxious to explain the normativity of law without any recourse to such an ideal or normative foundation for law. And so they fail to offer the judges who adopt their view of law anything more than a claim about discretionary power which is most implausible to just those judges.

The reasons which lay behind Hart's initial determination to do without a normative basis for positivism had to do, I think, with theoretical commitments of the time to value-neutral inquiry. One can see the persistence of these commitments in Hart's recent restatement of a theoretical need to purge descriptions of legal 
institutions of evaluative claims..$^{70}$ One can also see them in Raz's assertion that there are in principle legally determined answers to very difficult points of law that turn on issues of fact, but no such answers to relatively simple moral inquiries. ${ }^{71}$

It is part of Dworkin's great and continuing accomplishment to have attempted to restore legal philosophy to an examination of its proper, pragmatic roots by reuniting the central questions of legal and political philosophy. My aim in this article has been to argue that the cost for contemporary positivists of resisting this attempt is an unwitting collaboration in an authoritarian political project of which they should want no part.

70. Hart, “Comment," pp. 36-37.

71. For example, "Authority, Law and Morality," p. 319. 